\title{
Visitors Push Motivation Factors to Visit Seren Taun Reconstructive Ceremony in Sindang Barang Cultural Village Bogor, Indonesia
}

\author{
Seruni Dinitri \\ Post Graduate \\ Sekolah Tinggi Pariwisata Trisakti \\ Jakarta, Indonesia \\ seruni.dinithree@gmail.com
}

\begin{abstract}
Sindang Barang cultural village is one of valuable places in Bogor that very rich of historical and cultural value such Seren Taun as a traditional ceremony per year. Since 2005, Seren Taun in Sindang Barang Cultural Village has undergone several developments and has been reconstructed as a part of industrial products in the tourism sector. There are many attraction has been offered for the local societies and also non local societies. Besides attraction, people would like to visit some destination also due to other factors. Psychological factors such as motivation, perception, learning, personality, and attitudes, influencing visitors to decide where they will visit. The purpose of this study is to describe the push motivation factors that encourage visitors to visit Seren Taun Reconstructive Ceremony in Sindang Barang Cultural Villlage, Bogor, Indonesia. Samples of 90 questionnaires were completed by giving a set of written statement to the respondent to be filled. This study is using descriptive design. Sampling method is by using Non Probability Accidental Sampling. The result shows that subvarible of visitors push motivation factors to visit Seren Taun ceremony, the biggest score is enjoying natural resources, the lowest score is family $\&$ friend togetherness, and the categorization of scoring result of visitors's reponse to visit Seren Taun in Sindang Barang Cultural Village is "Strongly Agree". It shows visitors have the strong push motivation factor to visit Seren Taun Constructive Ceremony in Sindang Barang Cultural Village.
\end{abstract}

Keywords-Push Motivation, Seren Taun Reconstructive, Sindang Barang Cultural Village

\section{INTRODUCTION}

Sindang Barang cultural village is one of valuable places in Bogor that very rich of historical and cultural value such as 99 point of archeological sites, Taman Sri Baginda, and Seren Taun as a traditional ceremony per year. Sindang Barang cultural village is located in Pasir Eurih Village Taman Sari District Bogor regency, West Java. It is located just $5 \mathrm{~km}$ from city of Bogor, as the oldest village on area of town and district of Bogor, based on the source text of Pantun Bogor, as is an old script that serves as a reference for the history of the Bogor Sundanese people.

Seren Taun has undergone several developments. Initially this ceremony is an expression of gratitude among local societies for yields, a form of embodiment viewpoint maintain the natural balance of micro and macro. Before it held simultaneously in 2005, the celebration was held individually and sacred. Since 2005, Seren Taun ceremony is revitalized initiated by Padepokan Giri Sunda Pura Sindang Barang. Culture in the revitalization, according to Susamto (2008) is no longer sacred. So its called Seren Taun Reconstructive. Seren Taun Reconstructive is a rearrangement of the Seren Taun ceremony that used to be a tradition of agrarian-based society and is now used for tourism needs with few changes.

In 2016, Seren Taun ceremony was held in October 15-16, 2016. There were many attraction has been offered for the local societies and also non local societies. The attraction such as cake charity event, slaughtering buffalo with Angklung Gubrag (a traditional musical instrument made of black bamboo), performing art, and Helaran procession of yield with Dondang (an equipment to bring food at celebration or special event).

Besides attraction, people would like to visit some destination also due to other factors. Psychological factors such as motivation, perception, learning, personality, and attitudes, influencing visitors to decide where they will visit. (Schiffman and Kanuk 2008: 7). Motivation is fundamental in the study of tourists and tourism, because motivation is the "Trigger" from the process of travel, even if the motivation is often not realized fully by the tourists themselves (Pitana dan Gayatri 2005:58 in Hermansyah , 2012)

Motivation according Pitana and Gayatri (2005: 66) is the push and pull factors. Push factors and pull factors are actually the internal and external factors that motivate visitors to visit Seren Taun Reconstructive Ceremony in Sindangbarang Cultural Village, Bogor

According to Alghamdi (2007: 46) the driving factors that motivate visitors to visit tourism destination consists of: escape motives, relaxation, prestige, family and friend togetherness, knowledge, sport motivations, adventure, enjoying natural resources, desire for sex, motivations of alcohol consumption. This study describes the motivation of escape motives, relaxation, family and friend togetherness, knowledge, adventure, enjoying natural resources. But for sport motivation, prestige, desire for sex, motivations of alcohol consumption are not examined because it does not comply with the conditions in 
the field. Operational variable of push motivation factors are in table 1 .

This study purpose is to describe the push factors that motivating visitors to visit Seren Taun Reconstructive Ceremony in Sindang Barang Cultural Villlage, Bogor, Indonesia.

\section{METHOD}

A sample of 90 questionnaires were completed by giving a set of written statement to the respondent to be filled among visitors. The list of visitor's database from Cultural Village Sindang Barang is 112 visitors.

This study is using descriptive design. Descriptive research is research conducted to determine the value of an independent variable, either one or more variables (independent) without making comparisons, or connect with other variables (Sugiyono, 2013). Sampling method is by using Non Probability Accidental Sampling and using the formula of Slovin with error tolerance is $5 \%$.

Table 2 shows that subvarible of visitors push factor motivation to visit Seren Taun ceremony in 2016, the biggest score is enjoying natural resources $(17.33 \%)$ followed by knowledge (17.23\%), adventure (16.95\%), escape motives $(16.70 \%)$, relaxation $(16.49 \%)$, and the lowest is family \& friend togethernes $(15.30 \%)$. It shows us that natural resources in Sindang Barang Cultural Village make visitor's interested to see Seren Taun ceremony. Its means that the natural resources in Sindang Barang has a high selling power to support Seren Taun ceremony.

Increasing knowledge is the second push motivation factor to visit Seren Taun ceremony. This result in accordance with Prasetyo (2011) that stated Seren Taun ceromony can give knowledge to the visitors about the meanings contained in Seren Taun ceremony itself. It means that visitors want to acquire knowledge and broaden their intellectual by watching the agenda of Seren Taun Ceremony.
TABLE I. OPERATIONAL VARIABLE OF PUSH MOTIVATION FACTORS

\begin{tabular}{|c|c|c|c|}
\hline $\begin{array}{l}\text { Sub- } \\
\text { Variable }\end{array}$ & Statement & Scale & Source \\
\hline $\begin{array}{l}\text { Escape } \\
\text { Motives }\end{array}$ & $\begin{array}{l}\text { The escape motive } \\
\text { reflects the } \\
\text { individual's wish to } \\
\text { escape from his/her } \\
\text { personal } \\
\text { environment } \\
\text { (pressure, stress), as } \\
\text { well as from his/her } \\
\text { interpersonal } \\
\text { environments } \\
\text { (employer, } \\
\text { colleagues, family) }\end{array}$ & $\begin{array}{l}\text { Ordinal } \\
\text { 1. Strongly } \\
\text { disagree } \\
\text { (SD) } \\
\text { 2. Disagree } \\
\text { (D) } \\
\text { 3. Somewhat } \\
\text { Agree } \\
\text { (SA) } \\
\text { 4. Agree (A) } \\
\text { 5. Strongly } \\
\text { Agree }\end{array}$ & $\begin{array}{l}\text { Al Ghamdi } \\
(2007: 46)\end{array}$ \\
\hline Relaxation & $\begin{array}{l}\text { Activities that do not } \\
\text { lead to any stress or } \\
\text { tension }\end{array}$ & (SA) & $\begin{array}{l}\text { Al Ghamdi } \\
(2007: 49)\end{array}$ \\
\hline Family \& & The pleasure vacation & & Al Ghamdi \\
\hline $\begin{array}{l}\text { Friend } \\
\text { Togetherness }\end{array}$ & $\begin{array}{l}\text { has the function of a } \\
\text { way in } \\
\text { which family } \\
\text { relationships can be } \\
\text { enhanced or enriched }\end{array}$ & & \\
\hline Knowledge & $\begin{array}{l}\text { Increasing Knowledge } \\
\text { is the wish to acquire } \\
\text { knowledge and } \\
\text { broaden intellectual } \\
\text { horizons }\end{array}$ & & $\begin{array}{l}\text { Al Ghamdi } \\
(2007: 55)\end{array}$ \\
\hline Adventure & $\begin{array}{l}\text { An exciting experience } \\
\text { which comes about } \\
\text { through } \\
\text { unknown unusual or } \\
\text { even dangerous } \\
\text { occurrences, or as an } \\
\text { undertaking involving } \\
\text { unknown risks }\end{array}$ & & $\begin{array}{l}\text { Al Ghamdi } \\
(2007: 59)\end{array}$ \\
\hline $\begin{array}{l}\text { Enjoying } \\
\text { Natural } \\
\text { Resources }\end{array}$ & $\begin{array}{l}\text { The desire of tourists } \\
\text { to enjoy the natural } \\
\text { recourses such as } \\
\text { wilderness and } \\
\text { undisturbed areas, } \\
\text { national parks/forests, } \\
\text { rivers, } \\
\text { rural areas and nice } \\
\text { weather, } \\
\text { snow/mountains and } \\
\text { so on, which are } \\
\text { available in } \\
\text { specific destinations }\end{array}$ & & $\begin{array}{l}\text { Al Ghamdi } \\
(2007: 60)\end{array}$ \\
\hline
\end{tabular}

\section{RESULTS \& ANALYSIS}

Based on data collection, obtained recapitulation of Visitors feedback can be seen on table 2. Furthermore, adventure is the third push motivation factors to visit Seren Taun ceremony. It means that visitors would like to get an exciting experience by visiting Seren Taun Ceremony. 
TABLE II. RECAPITULATION OF VISITOR'S RESPONSE TO VISIT SEREN TAUN CONSTRUCTIVE CEREMONY

\begin{tabular}{|c|c|c|c|c|c|}
\hline No & $\begin{array}{l}\text { Total } \\
\text { Score }\end{array}$ & SubVar & $\begin{array}{l}\text { Item of } \\
\text { Question }\end{array}$ & Average & $\%$ \\
\hline 1 & 364 & $\begin{array}{l}\text { Escape } \\
\text { Motives }\end{array}$ & 1 & 364 & $16.70 \%$ \\
\hline 2 & 360 & Relaxation & 1 & 360 & $16.49 \%$ \\
\hline 3 & 334 & $\begin{array}{l}\text { Family \& } \\
\text { Friend } \\
\text { Togetherness }\end{array}$ & 1 & 334 & $15.30 \%$ \\
\hline 4 & 376 & Knowledge & 1 & 376 & $17.23 \%$ \\
\hline 5 & 370 & Adventure & 1 & 370 & $16.95 \%$ \\
\hline 6 & 378 & $\begin{array}{l}\text { Enjoying } \\
\text { Natural } \\
\text { Resources } \\
\end{array}$ & 1 & 378 & $17.33 \%$ \\
\hline TOTAL & 2182 & & & 2182 & $100 \%$ \\
\hline
\end{tabular}

Escape motives only got $16.70 \%$ as the visitors push motivation factors. It indicates that visitor's major reason to come to Seren Taun ceremony is not because of escaping from the routines or personal environment.

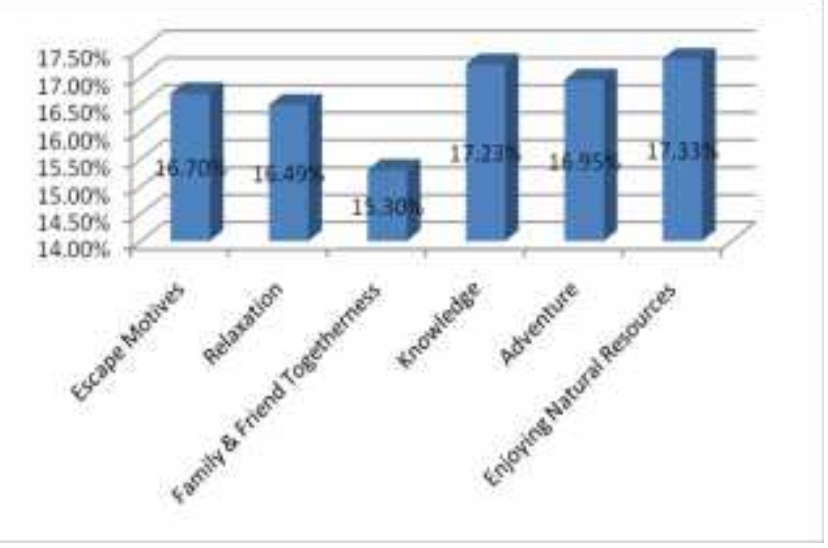

Fig. 1. Recapitulation of Visitor's Response to Visit Seren TAun Reconstructive Ceremony

This study also showed that relaxation is not the major push motivation factors for Seren Taun Ceremony visitors. This result is quite different with Hermansyah (2012) study. Relaxation got the highest score for push motivation factors that visit Bogor Botanical Garden. It indicates visitors push motivations in Seren Taun ceremony are not just for relaxation.

The lowest score is Family \& Friend togetherness. The same result with Hermansyah (2012) study about Push motivation factor in Botanical Garden. Hermansyah argue that it is because lack of supporting facilities to gather or strengthen kinship.

The data processing is presented in the form of figure 1.Overall response of visitors on the analysis of the push motivation factors to visit Seren Taun Reconstructive in Sindang Barang Cultural Village can be determined based on the scores obtained from the data in Table 2. This value is compared with a criterion standard score obtained by calculating the ideal score (criterium) and the score of the smallest, so that through a standard score can be known areas continum that shows the ideal place of variable analysis of the push factor motivation to visit Seren Taun ceremony, it can be obtained through a Sugiyono formula (2008: 141). Ideal Score $=5$ (the highest score) $\times 6$ (total question/statement) $\times 90$ (total respondent) $=2700$

The lowest Score $=1$ (the lowest score) $\mathrm{x} 6$ (total question/statement)x 90 (total respondent) $=540$

The length of interval class: 2700 (ideal score) : 5 (The number of class interval) $=540$

We can see from Table 2 that the total score of Visitor's response to visit Seren Taun constructive ceremony is $\mathbf{2 1 8 2}$.

The results of the formula according to Sugiyono (2008: 141 ) is used in the discussions to determine the responses of visitors on an analysis of the push factors to visit Seren Taun Ceremony in Sindang Barang Cultural Village, Bogor. The scoring is 2182. The categorization of scoring result of visitors's reponse to visit Seren Taun in Sindang Barang Cultural Village "Strongly Agree". It shows visitors have the strong push motivation factors to visit Seren Taun Constructive Ceremony in Sindang Barang Cultural Village.

\section{CONCLUSION}

Based on the study that has been analyzed using decriptive about visitors push motivation factors to visit Seren Taun Reconstructive Ceremony in Sindang Barang Cultural Village, Bogor District, show us that from six subvariables of push motivation factors: escape motives, relaxation, family \& friend togetherness, knowledge, Adventure, and enjoying resources, the biggest score is enjoying natural resources. The lowest score is Family \& Friend togetherness. But for overall response of visitors on the analysis of the push motivation factors to visit Seren Taun Reconstructive in Sindang Barang Cultural Village, the categorization of scoring result of visitors's reponse to visit Seren Taun in Sindang Barang Cultural Village is "Strongly Agree". It shows visitors have the strong push motivation factor to visit Seren Taun Constructive Ceremony in Sindang Barang Cultural Village.

\section{REFERENCE}

Alghamdi, A. (2007). Explicit And Implicit Motivation Towards Outbound Tourism: A Study of Saudi Tourists. Thesis.

Hermansyah, D., \& Waluya, B. (2012). Analisa Faktor-Faktor Pendorong Motivasi Wisawatan nusantara terhadap Keputusan Berkunjung ke Kebun raya Bogor. Tourism and Hospitality Essentials (THE) Journal, 2(1), 2012 268.

Kassean, H., \& Gassita.R. (2013). Exploring Tourist Push and Pull Motivations to Visit Mauritius as a Tourist Destination. African Journal of Hospitality, Tourism and Leisure, 2(3) - (2013). ISSN: 2223-814.

Pitana, I.G., \& Gayatri P.G. (2005). Sosiologi Pariwisata. Yogyakarta: Andi Offset.

Prasetyo, U. (2011). Komodifikasi Upacara Tradisional Seren Taun dalam pembentukan Identitas Komunitas. Institute Pertanian Bogor. Skripsi. 
Schiffman, L. G., \& Kanuk L.L. (2008). Perilaku Konsumen, Edisi 7, Jakarta: Indeks.

Siswanto,S. (2009). Manajemen Pemasara Untuk Eksekutif Non-Pemasaran, Jakarta: Damar Mulia Pustaka.

Sugiyono. (2013). Metode Penelitian Administrasi. Bandung. Alfabeta
Sugiyono. (2008). Metode Penelitian Bisnis. Bandung: Alfabeta

Susamto, D.A. (2008). Hibrida Lokal-Global pada Politik Komodifikasi Budaya Seren Taun Rekosntruktif, Upacara Tahunan Masyarakat Sunda, di Sindang Barang Kabupaten Bogor. Universitas Indonesia.Thesis. 